\title{
Feasibility Study for an Additional HEPA Filter Leaching System in NWCF
}

\author{
Walter D. Willis
}

Published November 1992

Idaho National Engineering Laboratory EG\&G Idaho, Inc. Idaho Falls, Idaho 83415

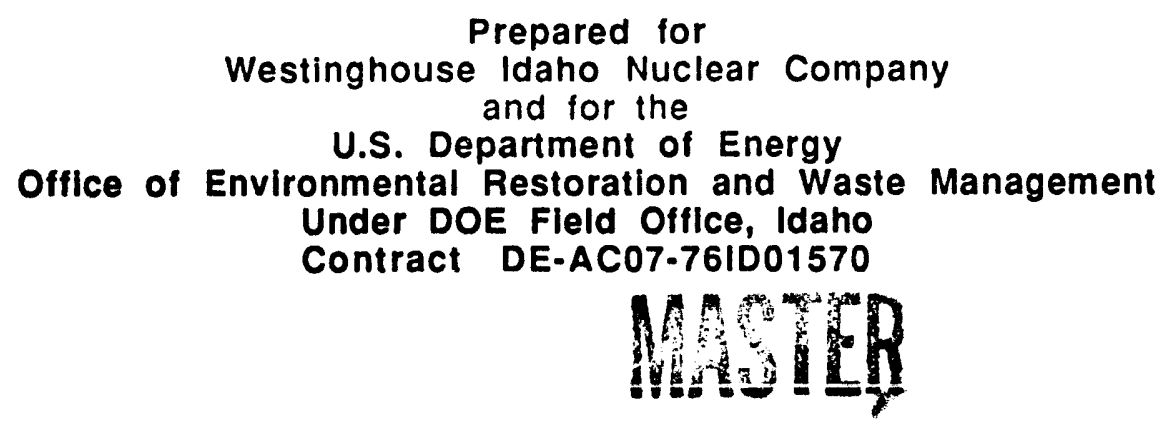




\section{ABSTRACT}

This report documents the feasibility of installing a second high-efficiency particulate air (HEPA) filter leaching system in the New Waste Calcining Facility at the Idaho Chemical Processing Plant (ICPP). A large spent filter backlog already exists at the ICPP, and it has been uncertain whether the existing HEPA filter leaching system will have a throughput rate sufficient to work off the existing backlog in a timely manner. Three areas within the New Waste Calcining Facility (NWCF) have been identified as possible locations for a second filter leaching system. This report examines the suitability of each location, identifies modifications that would be necessary to install a filter leaching system at each location, examines the impact of modifying each location, and discusses recent efforts to estimate filter throughput using the existing filter leaching system. Based on all available information, installation of a second filter leaching system is not recommended at the present time. 


\section{CONTENTS}

ABSTRACT

1. INTRODUCTION ….................................................................. 1

2. OVERVIEW OF EXISTING FILTER LEACHING SYSTEM …....................... 2

$2.1 \quad$ Facility Description …......................................................... 2

2.2 Leaching System Operation ……............................................. 2

3. FILTER LEACHING SYSTEM REQUIREMENTS …............................. 7

3.1 Leaching Room Location and Construction …................................ 7

3.2 Physical Space ….............................................................. 9

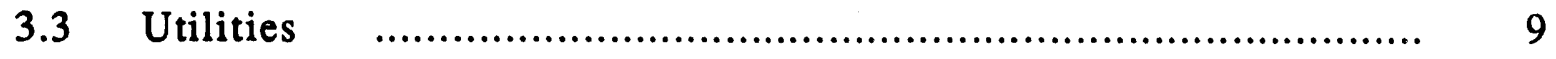

3.4 Remote Handling Equipment …................................................. 11

3.5 Leaching System Equipment ……............................................ 11

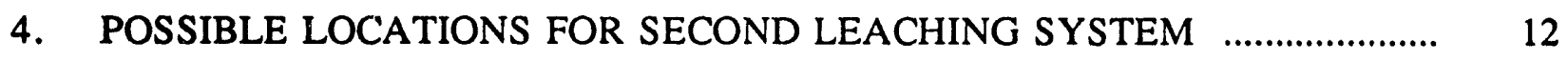

4.1 The Decon Cell ................................................................ 12

4.2 The Equipment Storage Area _................................................ 13

4.3 Decon Cubicle \#1 ....................................................... 15

5. FILTER BACKLOGS AND THROIGHPUTS …..................................... 17

5.1 Filter Backlogs …............................................................ 17

$5.2^{-}$Filter Throughputs _............................................................. 17

6. CONCLUSIONS AND RECOMMENDATIONS …..................................... 22 


\section{Feasibility Study for an Additional HEPA Filter Leaching System in NWCF}

\section{INTRODUCTION}

This report documents the feasibility of installing a second high-efficiency particulate air (HEPA) filter leaching system in the New Waste Calcining Facility (NWCF) at the Idaho Chemical Processing Plant (ICPP). The existing leaching system was placed in service in mid-1988, but was only operated for a short time. The original intent of the filter leaching system had been to remove transuranic (TRU) wastes from HEPA filters used in offgas process streams, but new regulations concerning hazardous materials made the removal of the hazardous materials an additional requirement of the system. The Resource Conservation and Recovery Act (RCRA), 40CFR Parts 260 through 270, specifies the allowable limits and analysis requirements for the classification of these hazardous wastes. The primary wastes of concern in the HEPA filters are heavy metals and the TRU wastes. Initial testing of the filter leaching system indicated that it would remove the heavy metals, but not consistently to below the RCRA limits. Westinghouse Idaho Nuclear Company's (WINCO's) Technical department subsequently began a testing effort to optimize leaching system parameters so that RCRA limits would always be met. The results of this testing led to a redesign of the leaching system, which is currently underway. References to the existing leaching system in the rest of this document will actually refer to the anticipated configuration of the redesigned leaching system, but the only significant difference between the two systems is the addition of a separate filter drying vessel in the redesigned system.

It has been estimated that there are approximately 300 spent HEPA filters currently stored at the ICPP. Filter sizes vary, ranging from $20.3 \mathrm{~cm} \times 20.3 \mathrm{~cm} \times 15.2 \mathrm{~cm}$ ( 8 inches $\times 8$ inches $\times 6$ inches) to $30.5 \mathrm{~cm} \times 61 \mathrm{~cm} \times 76.2 \mathrm{~cm}$ (12 inches $\times 24$ inches $\times 30$ inches). Storage space for these filters is extremely limited, and additional filters are being generated in the course of plant operations. Processing and disposal of the spent filters is necessary to safely continue the ICPP facility operations. It is conceivable that the existing HEPA filter leaching system would not provide filter throughputs sufficient to process the filter backlogs in a timely manner. This report identifies three areas within NWCF that could be dedicated to a second filter leaching system, specifies modifications necessary to install a second filter leaching system in each area, examines predicted filter throughput rates, and recommends possible courses of action based on all information currently available. 


\section{OVERVIEW OF EXISTING FILTER LEACHING SYSTEM}

\subsection{Facility Description}

The existing filter leaching system is located in the Decontamination Area of the NWCF. When the NWCF was designed in the mid-1970's, the western portion of the building was designated as a decontamination facility, where large and small items, with varying levels of contamination, could be decontaminated. Two connected cells were constructed on the second level of the Decontamination Area (see Figure 1). One cell, the Decon Cell, was intended for normal decontamination work. The second cell, adjacent to the the Decon Cell and designated the Filter Handling Cell, was intended for processing spent filters. A filter handling system was to be installed at a later date. Provisions were made in both cells for support utilities, remote handling, and viewing from the operating corridor. Both cells were designed so that items from the Calciner side of the NWCF could be remotely transferred to the Filter Handling Cell and the Decon Cell. This is done by remotely transferring items from the Valve Cubicle crane on the Calciner side to the Decon side crane in a transfer cell designed for this purpose.

The existing filter leaching system is installed in the Filter Handling Cell, which measures $4.9 \mathrm{~m}$ by $6.1 \mathrm{~m}$ ( 16 feet by $20 \mathrm{feet})$. The walls and ceiling of the cell are $0.9 \mathrm{~m}$ ( 3 feet $)$ thick reinforced concrete. The walls are lined with 10 gauge stainless steel sheet, and the floor is covered with $1.27 \mathrm{~cm}(0.5$ inch) stainless steel plate. An oil-filled radiation shielding window provides viewing of the interior of the cell from the operating corridor. Remote handling capabilities within the cell are available via a pair of master/slave manipulators on either side of the window and an overhead crane within the cell. An electro-mechanical manipulator $(\mathrm{PaR})$ is scheduled to be replaced on the south wall of the Decon Cell.

Hatch covers are located in the ceiling of the Filter Handling Cell. One of these hatches has a small plug which is sized to allow filter transfer from an existing bottom-loading filter transfer cask. The plug is designed to be removed with an overhead crane so that the cask can be placed over the opening, and the filter drum, which contains used filters from other facilities at the ICPP, can then be lowered from the cask into the Filter Handling Cell.

The physical arrangement of the filter leaching system within the Filter Handling Cell is shown in Figure 2. There are only four major pieces of equipment within the cell; the filter leaching vessel (including lid), the filter drying vessel (also including lid), the sampling station, and the filter handling table. These components are positioned so that they are visible from the Filter Handling Cell shielding window and accessible to the manipulators, and essentially define the envelope within the cell where work can be performed effectively. All instrumentation and controls for the filter leaching system are on a control panel in the operating corridor adjacent to the Filter Handling Cell shielding window. Process piping and service lines pass through the cell wall into the Filter Handling Cell (see Figure 3).

\subsection{Leaching System Operation}

This section describes how the leaching system is anticipated to operate. It has been assumed that sampling of the final leach solution will be the only sampling required to confirm adequate leaching has occurred. The leaching of a single, large filter is discussed, but it is expected that two or more large filters will be wun through the sy stem sequentially.

The filter to be leached will initially be staged on the filter handling table in the Filter Handling Cell. The filter could have been transferred from the Calciner side, or it could have been lowered onto the table through the overhead hatch. The first step is the breaching (puncturing) of the filter media. Breaching will be accomplished by either lowering the filter onto a filter breaching 


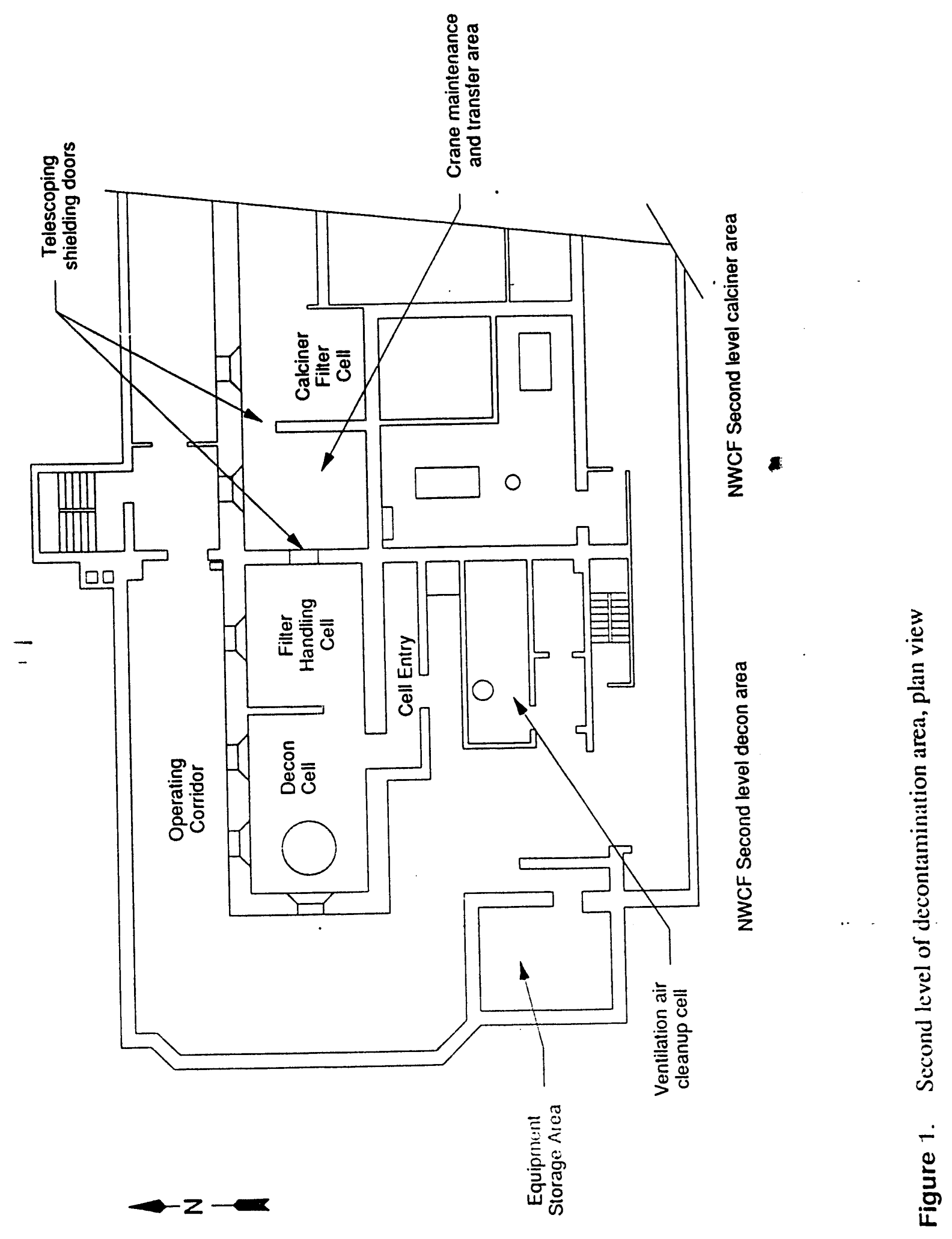




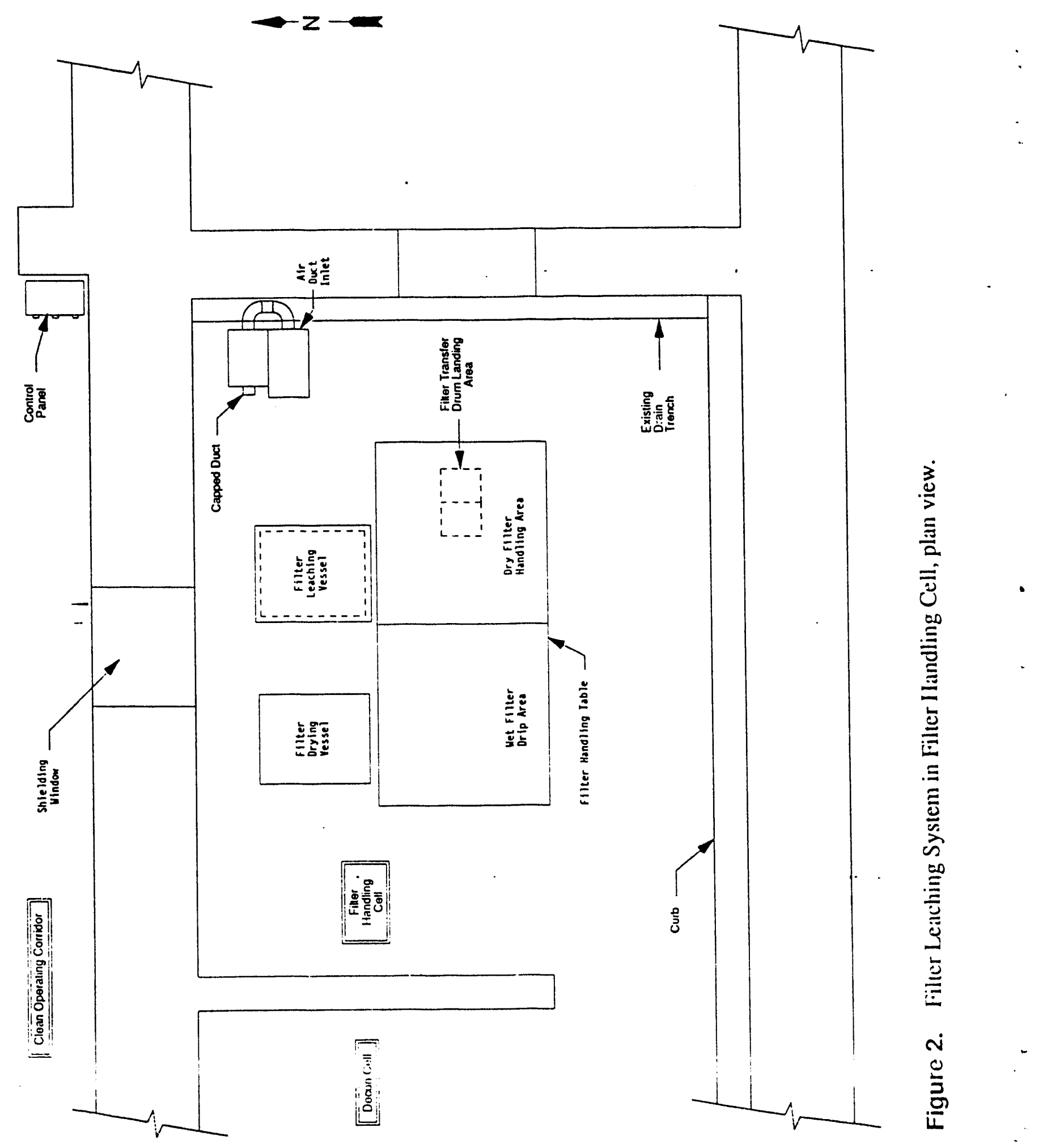




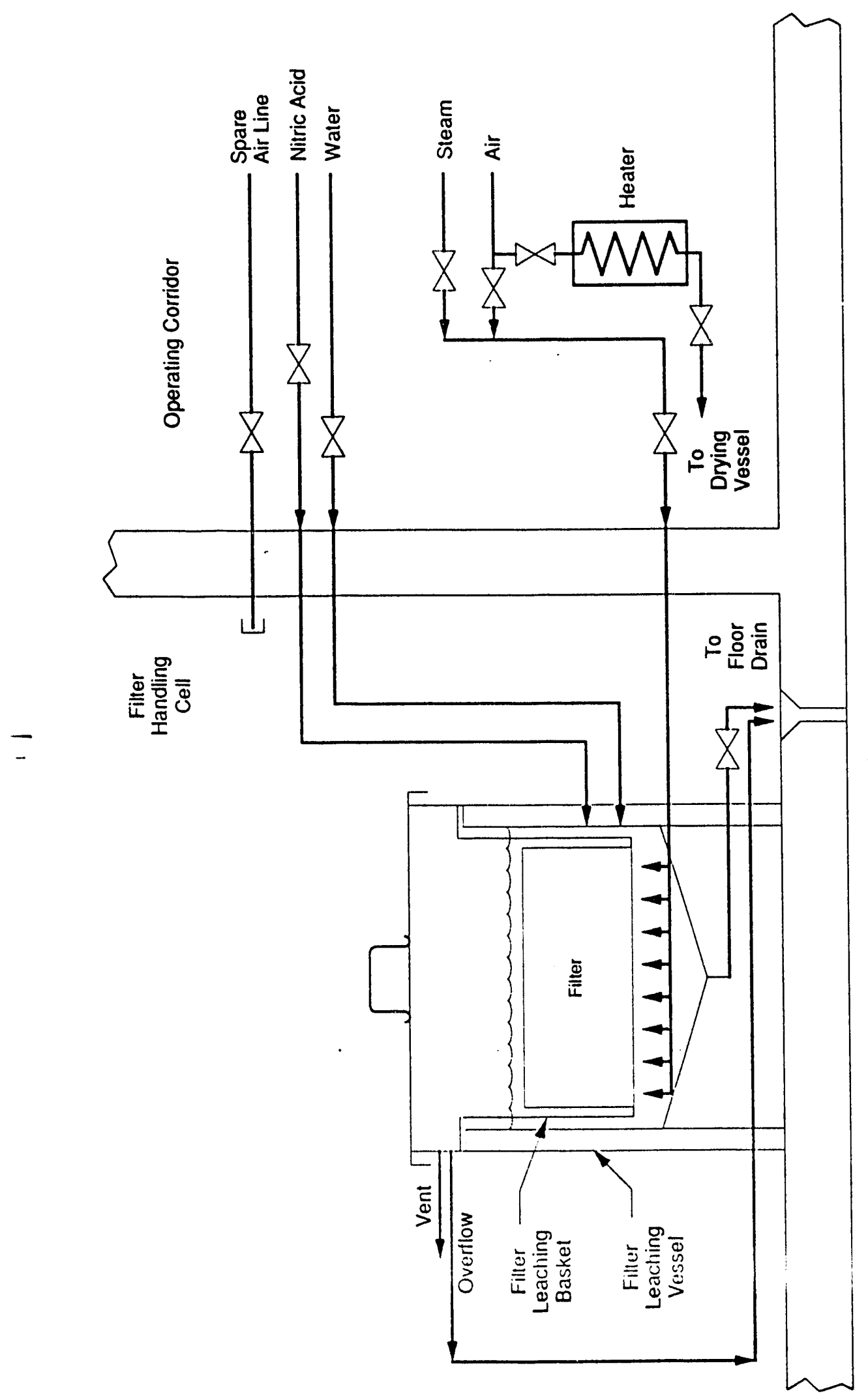

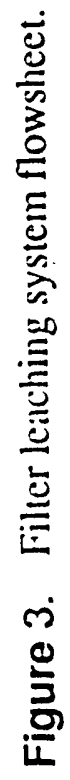


tool or lowering a filter breaching tool onto the filter. The filter will be breached several times so that the filter media is well punctured across the face of the filter. Provisions will be made to contain any media dislodged by breaching. Either one or both faces of the filter could be breached to promote flow through the filter. The filter is then placed back on the table, and the manipulators or the PaR are used to install a disposable screen over each face of the filter (assuming the disposable screens are used). The filter is then placed face down in a leaching basket, and the leaching basket is placed in the leaching vessel. The leaching vessel lid is placed on top of the leaching vessel, and the leaching steps are begun.

The required number of leaching cycles has not been finalized, but is expected to be five. Each leach cycle will be identical. The leaching vessel will be filled with heated $\left(60-70^{\circ} \mathrm{C}\right)$, low molarity (approximately $1 \mathrm{M}$ ) nitric acid until the filter is completely submerged. This level would be indicated on the control panel by a signal from the appropriate point-level indicator. An air sparge of up to 60 SCFM will then be applied to agitate and circulate the leaching solution. The filter will be leached for 30 minutes per leaching cycle, and the vessel will then be drained to a collection vessel via the cell gutter drain. A sample of the final leach solution will be taken remotely and sent to the Remote Analytical Laboratory (RAL) for analysis.

Two rinse cycles will probably be required. A rinse cycle will be identical to a leach cycle, except the rinse water will not be heated. Following the rinsing, the filter basket will be removed from the leaching vessel and placed on the filter handling table to drip-dry for one hour or more. After the filter has dripped sufficiently, the filter basket will be moved into the filter drying vessel. Drying will be performed in the drying vessel by flowing air through the air heater to raise the drying air temperature, then into the bottom of the drying vessel, through the filter, and out the vent at the top of the drying vessel. The drying air temperature is controlled to a setpoint using a temperature control system. After the filter has been dried, the filter basket will be removed from the drying vessel and placed in a temporary storage area within the Decon Cell.

If-analytical results indicate the filter does not meet disposal criteria, the filter will be releached. If the filter does meet disposal criteria, the filter will be removed from the leaching basket by either inverting the basket or by using the filter handling tool. In the event the filter media has come apart, the option is available to leave the filter in the filter basket for disposal. The treated filter will then be placed in a waste storage box within the Decon Cell or the Filter Handling Cell pending removal of the filled waste storage box and final disposal at the Radioactive Waste Management Complex (RWMC). 


\section{FILTER LEACHING SYSTEM REQUIREMENTS}

The physical requirements for a filter leaching system, including utilities, remote handling equipment, physical space, and leaching system equipment, are listed to clarify evaluation of the areas identified within NWCF which could be modified for an additional leaching system. Filter leaching system requirements are based primarily on the design and operation of the existing filter leaching system.

\subsection{Leaching Room Location and Construction}

Several criteria affect the suitability of any room or area that is to considered as a possible site for a second leaching system.

\subsubsection{Location}

Ideally, a new leaching system should be located within the Decontamination side of NWCF. All leasching operations are to be performed by Decontamination personnel, therefore it would be best to have the leaching system located where all equipment and operations fall under their sole jurisdiction. The filter leaching room should be readily accessible from the Equipment Decon Room since that is where incoming and outgoing filters will generally be staged. The Equipment Decon Ruom occupies the north half of the first level of the Decontamination side (see Figure 4). It is used io decon large equipment and contains the truck bay, two decon cubicles, the airlock transfer room, and the steam spray booth. Removable hatches within the Equipment Decon Room provide access 10 the Decon Cell, the Filter Handling Cell, the Equipment Storage Area, and the decon cubicles.

\subsubsection{Hatches and Clearance Above Hatches}

The roof of the leaching room must have provisions to allow the remote transfer of filters, and possibly the remote transfer of waste boxes, into and out of the leaching room. This could be accomplished with a roof that is a single hatch or a system of hatches that are removable A removable plug could also be designed into a hatch for unloading filter casks or lowering individual filters into the leaching room. One of the Filter Handling Cell roof hatches currently incorporates this feature.

There must be sufficient clearance between the Equipment Decon Room bridge crane and the roof of the leaching room to allow handling of filter casks and their associated rigging. Decontamination personnel have indicated that the minimum clearance required is approximately 12.5 feet based on the largest filter cask currently used.

\subsubsection{Stainless Steel Lining}

Leached filter media can become quite brittle and has shown a tendency to powder and become airborne when handled directly. Epoxy-coited concrete is suitable for many applications, but is not desirable in a remote leaching room. The epoxy coating has an uneven surface which collects particles, it can become porous when exposed to acid, and it tends to stain and flake over time. The interior floor and walls of the filter leaching room should be lined with buffed stainless steel so that it can be decontaminated effectively:

\subsubsection{Radiation Shielding}

The construction of the leaching room must provide adequate radiation shielding to protect personnel. The radiation levels of the filters to be leached, particularly the gamma radiation levels, 


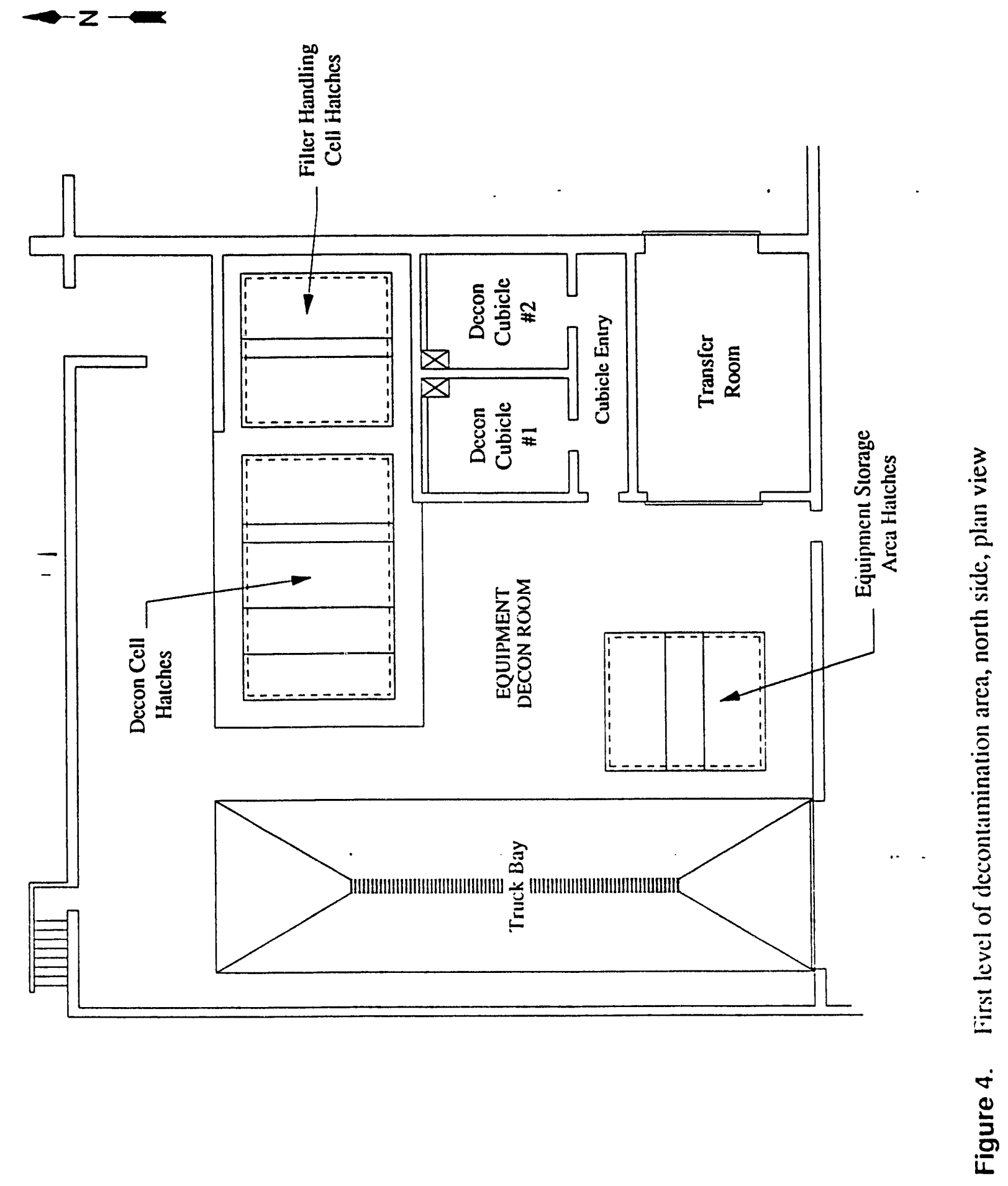


will affect the amount of shielding required. The number of filters allowed in the leaching room will also affect the amount of shielding required. The modification of an existing area for a new filter leaching system may make it undesirable or not feasible to add shielding in excess of what is currently in place. If this is true, allowable filter radiation levels will have to be determined on a case-by-case basis for each area. Building CPP-659 is classified as a Radioactive Materials Area (RMA), so areas with body fields of up to $5 \mathrm{mR} / \mathrm{hr}$ are not required to be posted.

\subsection{Physical Space}

\subsubsection{Inside Leaching Room}

The existing leaching system has a footprint approximately $11 \mathrm{ft}$ wide and $9 \mathrm{ft}$ deep. This could be reduced somewhat by downsizing the filter handling table, but in general a larger table allows more operational flexibility. The existing filter handling table has a work surface measuring $10.75 \mathrm{ft}$ by $5.0 \mathrm{ft}$. If space were limited, a filter handling table measuring 9 ft by $4.5 \mathrm{ft}$ would provide an adequate working surface for 'aandling the larger filters and would reduce the leaching system footprint to approximately $9 \mathrm{ft}$ ride by $8 \mathrm{ft}$ deep.

The required ceiling height within the leaching room is dependent upon whether or not an overhead crane is installed. As a minimum, the ceiling inside the leaching room would have to be at least $10.75 \mathrm{ft}$ higher than the $\mathrm{f}$, or outside the leaching room to allow installation of master/slave manipulators. Three or more additional feet of ceiling height would be required to install an overhead crane in the leaching room.

\subsubsection{Outside Leaching Room}

The existing system occupies approximately 12 linear feet of wall on the outside of the Filter Handling Cell, and most of the system equipment is mounted at or below an eight foot level. The one exception is the master/slave mianipulators, which are mounted above the viewing window at ten feet off the ground and require over two feet of clearance above that point for counterweight clearance. Clear space requirements away from the wall vary. Four to six feet of clearance away from the wall will be adequate for personnel to operate controls and manipulators, but 12 to 13 feet of clearance would be required at the $10 \mathrm{ft}$ level to install new master-slave manipulators.

\subsection{Utilities} below.

The utilities necessary to operate a filter leaching system are not extensive, and are detailed

\subsubsection{Piped Fluids and Gases}

Piped fluid and gas supply lines required for actually leaching and drying filters are: 1) One 1 inch low pressure steam line, 2) One 1 inch low pressure air line, 3) One 1 inch raw water line, and 4) One 1 inch decontamination solution line. These lines must be available outside the room where leaching is to be performed to allow manual control of flow and to provide accessibility to valves and equipment for maintenance. Lines which penetrate the room wall and connect the supply lines to the leaching and drying equipment are: 1) One 1 inch line used for both steam and air sparging. 2) One 2 inch line for heated drying air. 3) One 1/2 inch air line for purging the leaching vessel drain, 4) One 1 inch raw water line for rinsing, and 5) One 1 inch decontamination solution line for leaching. A schematic diagram of a filter leaching system can be seen in Figure 3 on Page 5. 
Additional piped flúids will be required within the room. Decontanination solution must be available to decontaminate the interior of the : $\mathrm{m}$; either through a decontamination spray header for remote decoivamination, or through a quick-connect system for manual decontamination via a personnel entry. A fire protection system will apparently be required within the room because of the oil-filled stielding window. A Fire Hazards Analysis would have to be done to determine the appropriate type of system for each location.

\subsubsection{Ventilation/Off-Gas Removal}

The leaching room must have a ventilation/off-gas system that will constantly maintain a negative pressure in the rrom such that air only leaves the room through an exhaust header that connects to the Calciner Exhaust System or the scrubber system. This is required to prevent the uncontrolled movement or release of acid fumes and airborme particles.

\subsubsection{Electrical}

One or two 480 Volt, 3 phase electrical circuits will be required. One circuit will supply power to the leaching system control panel, which in turn powers all system controls, instrumentation, and the electric drying air heater. The second circuit will supply power to an overhead crane or $\mathrm{PaR}$ manipulator in the leaching room, if such a device is required and not currently installed.

\subsubsection{Drains to Collection Vessels}

It is necessary to drain leach and rinse solutions from the leaching room to a collection vessel located in NWCF. Ther are two collection vessels available; VES..NCD-129, which holds 530 gallons, and VES-NCD-123, which holds 3800 gallons. It is currently planned to drain leach and rinse solutions to VES-NCD-123. Solutions in VES-NCD-123 would ultimately be jetted or pumped to the tank farm. The leaching vessel should have the capability of draining to either of the collection vessels to provide operational flexibility.

\subsubsection{Leachate Sampling}

The capability to sample leaching vessel solutions remotely is expected to be a requirement. It is likely that the final leach solution will have to be analyzed to determine whether or not leaching has been successful. Ideally, the capability should exist to pull leaching vessel solution samples directly from the leaching vessel at the Liquid Sample Station, which is located on the second level of the Calciner side of NWCF. This capability would minimize handling and expedite pneumatic shipment to the RAL. Other methods of getting samples to RAL, including the use of a double door transfer system or a cell entry, are less than ideal because of ALARA considerations.

\subsubsection{Lighting}

Lights within the leaching room must provide the illumination necessary for performing remote handling operations while looking through an oil-filled shielding window. Multiple, distributed light sources must be available so that shadows will not be formed that interfere with the operator's visibility. 


\subsection{Remote Handling Equipment}

\subsubsection{Master-Slave Manipulators}

At least one pair of master-slave manipulators will be required to remotely handle filters and filter baskets during leaching operations. The existing system uses one pair of Central Research Laboratories Model-F manipulators, which have a manufacturer's stated handling capacity of up to $100 \mathrm{lb}$.

\subsubsection{Oil-Filled Shielding Window}

At least one oil-filled shielding window will be required to provide viewing of the interior of the leaching room during leaching operations. The window must provide a level of radiation shielding greater than or equal to that provided by the leaching room wall.

\subsubsection{Overhead Crane}

Several factors will determine whether or not an overhead crane will be required within the leaching room. One factor will be the number and size of filters to be leached. If the smaller filters are to be leached individually, then the leaching system equipmerit can be downsized and remote handling could be done exclusively with master-slave manipulators. If larger filters or multiple smaller filters are to be leached, then either an overhead crane or possibly a PaR manipulator will be required to remotely handle the higher weights involved. A second factor determining the need for an overhead crane in the leaching room will be the availability of other remote handling equipment. It is conceivable that an overhead crane outside the leaching room could be used in place of an in-room crane, but this would necessitate removal of ceiling hatches, and would probably have limited application. A PaR manipulator within the leaching room might also provide the necessary lifting capacity, but room size and manipulator capabilities would have to be examined carefully. A third factor is the amount of ceiling space available within the leaching room. As mentioned earlier, the ceiling of the leaching room must be at least $14 \mathrm{ft}$ high to allow installation of an overhead crane above the master-slave manipulators.

\subsubsection{Electromechanical (PaR) Manipulator}

The Filter Handling Cell, which contains the existing leaching system, was designed to share a PaR electromechanical manipulator with the Decon Cell. The PaR never worked properly, and was never used with the existing leaching system. A replacement $\mathrm{PaR}$ is scheduled to be installed, but its usefulness with the leaching system is unknown. Under the right conditions, a $\mathrm{PaR}$ could conceivably prorm the functions historically performed by the in-cell crane, or it could simplify filter handling operations nomally performed by master-slave manipulators.

\subsection{Leaching System Equipment}

It is assumed that a new filter leaching system would differ little from the existing system. If the decision were made to treat only the smaller filters in a new leaching system, the basic equipment would remain the same, but might need to be resized to minimize the amount of leachate produced. The only significant requirement for leaching system equipment is that all components located within the leaching room must be makle of or covered by stainless sted to survive the acid environment. Refer to Section 2 if this document for a description of existing leaching system equipment. 


\section{POSSIBLE LOCATIONS FOR SECOND LEACHING SYSTEM}

Three areas within the Decontamination side of NWCF were identified as possible locations for installation of a second filter leaching system. These areas are: 1) The Decon Cell (Room 308), which is located on the second level of the facility and connected to the Filter Handling Cell, 2) The Equipment Storage Area (Room 306), which is also located on the second level of the facility, and 3) Decon Cubicle \#1 (Room 421), which is located on the first level of the facility within the Equipment Decon Room.

\subsection{The Decon Cell}

\subsubsection{General}

The Decon Cell is located on the second level of the Decontamination Area, and is connected to the Filter Handling Cell. A partial shielding wall separates the two cells (See Figure 1 on Page 3). The Decon Cell is used to dissassemble and decontaminate equipment with a minimum of personnel radiation exposure. Items with radiation levels up to $100 \mathrm{R} / \mathrm{hr}$ can be brought into the Decon Cell witn a resulting body field of $0.125 \mathrm{mR} / \mathrm{hr}$ or less one foot from the wall in the operating corridor. The Zone III contamination rating allows items with high contamination potential to be worked on. The Decon Cell was specifically designed so that equipment from calcining and associated operations can be removed, decontaminated, maintained, and returned to service without any direct hands-on contact. Equipment capable of being remotely moved to and cleaned in the Decon Cell includes valve loops, airlift and feed flowmeter loops, and solid sampling components. The Decon Cell can also be used for decontaminating items from other areas at the ICPP by bringing them into the truck bay, removing the cell hatches, and lowering them into the cell using the Equipment Decon Room 30/5 ton bridge crane. If items being moved are highly radioactive, the Equipment Decon Room can be cleared and the crane operated from a shielded position on the chemical storage mezzanine.

\subsubsection{Physical Description}

Five removable, interconnecting hatches allow access to the interior of the Decon Cell from the Equipment Decon Room, and there is over 20 feet of clearance between the hatches and the Equipment Decon Room bridge crane. The Decon Cell measures $24 \mathrm{ft} \times 16 \mathrm{ft}$ inside, and has a 19 foot ceiling. All walls are three foot thick high-density concrete, and three oil-filled shielding windows allow viewing of the interior of the cell from the operating corridor. The entire interior of the Decon Cell, including the bottom of the hatches, is lined with stainless steel. All piped fluids and gases required for a filter leaching system are already available outside the Decon Cell, and the Decon Cell can be drained to either VES-NCD-123 or VES-NCD-129. Facility drawings and specifications indicate that the cell ventilation system is designed to maintain a negative pressure of -1.0 inches WG within the cell. Ventilation air is normally pulled from the Decon Cell into the Filter Handling Cell exhaust outlet, and ultimately to the scrubber system. A decontamination spray header and deluge fire protection system are already present inside the cell. Lighting inside the Decon Cell is good, as would be expected in an area designed for remote handling operations. A pair of master-slave manipulators are available above each shielding window, and the Decon Cell shares a 5 ton overhead bridge crane with the Filter Handling Cell. A PaR electromechanical manipulator is scheduled to be reinstalled and will also be shared with the Filter Handling Cell. Several pieces of equipment. including an 8 it diameter rotary tumtable. are currently installed inside the Decon Cell to aid in decontamination operations. 


\subsubsection{Modifications Required to Install Leaching System}

Relatively few modifications would have to be made to install a second filter leaching system in the Decon Cell. The decon equipment, especially the turntable, would have to be removed to provide adequate floor space. Existing one inch lines for steam, air, raw water, and decon solution which penetrate the cell wall could be used to supply a new system, or new lines could be brought in. A two inch drying air line and an electrical conduit would have to be brought through the cell wall in either case. A $480 \mathrm{~V}$ power circuit would also have to be identified and brought to the outside of the cell.

If these modifications were made, the only remaining step would be to purchase and install the leaching system equipment. Existing cell features, such as viewing windows on two walls, lots of floor space, and three pairs of master-slave manipulators provide a number of options in regard to the arrangement of leaching system equipment. It could be advantageous to place the filter handling table along the west wall of the cell so that two pairs of manipulators could be used for the more complex filter and filter basket handling operations.

\subsubsection{Advantages and Disadvantages to Modifying the Decon Cell}

The Decon Cell is the most suitable location for a second leaching system because of its high radioactivity limits, its proximity to the existing leaching system, and the limited number of modifications required. Unfortunately, installation of a second filter leaching system in the Decon Cell would remove the ability to decontaminate large, highly contaminated items there. Another location, such as the Equipment Storage Area, would have to be converted to a decon cell. This would result in a great deal of expense (on the order of two million dollars based on a recent cost estimate), and would severely impact the decontamination of items from the Calciner side because they would have to be taken from the Filter Handling Cell or Decon Cell up into the Equipment Decon Room, and then lowered into the new decon cell. This handling sequence would bring a much higher risk of exposing personnel and contaminating the facility, would be physically awkward, and would limit the radiation levels of contaminated items to less than $50 \mathrm{R} / \mathrm{hr}$ unless shielding were improved.

\subsection{The Equipment Storage Area}

\subsubsection{General}

The Equipment Storage Area is located on the second level of the Decontamination Area, and is south and west of the Decon Cell (See Figure 1 on Page 3). The Equipment Storage Area is used to store large items with high levels of radiation and contamination. Items whose total radiation field is equal to or less than $50 \mathrm{R} / \mathrm{hr}$ (gamma) at one foot can be brought into the Equipment Storage Area with a resulting body field not exceeding $0.125 \mathrm{mR} / \mathrm{hr}$ one foot from the wall in the operating corridor. The Zone 111 contamination rating allows items with high contamination (sealed in plastic or non-smearable) to be stored. Items are stored in the Equipment Storage Area by bringing them into the truck bay, removing the hatches, and lowering them into the cell using the Equipment Decon Room 30/5 ton bridge crane. If items being moved are highly radioactive, the Equipment Decon Room can be cleared and the crane operated from a shielded position on the chemical storage mezzinine.

\subsubsection{Physical Description}

Three removable, interconnecting hatches allow access to the interior of the Equipment Storage Area from the Equipment Decon Room, and there is over 25 feet of clearance between the hatches and the Equipment Decon Room bridge crane. The Equipment Storage Area measures 21 
ft $x 15 \mathrm{ft}$ inside, and has a 14 foot ceiling. All walls are two foot thick concrete, and there are no shielding vindows. A single, unshielded personnel door provides access from the operating corridor via a labrinth-type corridor. The entire floor and bottom six inches of the walls are lined with 1/4 inch stainless steel. The remainder of the walls are epoxy-coated concrete. All piped fluids and gases required for a filter leaching system are available outside the Equipment Storage Area, but access to them would require tapping into the large lines which supply most of the second level and are mounted on the outside wall. The Equipment Storage Area has a gutter drain, but it drains only to VES-NCD-123. Facility drawings indicate that the storage area ventilation system is designed to maintain a negative pressure of -0.5 inches WG within the room. Ventilation air is pulled through a filter in the Equipment Storage Area door, into the Equipment Storage Area exhaust outlet, and ultimately to the Calciner Exhaust System. No decontamination systems or fire protection systems are present inside the storage area. Lighting inside the Equipment Storage Area is sufficient for remote handling operations. No provisions exist for remote handling of any kind.

\subsubsection{Modifications Required to Install Leaching System}

Extensive modifications would have to be made to install a second filter leaching system in the Equipment Storage Area. The most significant modifications would be associated with installation of master-slave manipulators. The entire ceiling area and wall of the operating corridor above the nine foot level is extremely congested. HVAC ducting, large structural steel supports, and many pipes and conduits currently occupy this area and would have to be removed and modified or rerouted to aliow the proper clearances for installation and operation of the manipulators. A shielding window would have to be added, and the interior walls would have to be lined with stainless steel. An overhead crane would also need to be installed for remote lifting. A PaR might be used in place of a c ane, but it is believed that the size and shape of the room would favor the use of a crane. Al: iget fluids and gases would have to be tied into large existing lines and brought through the wall sinci no spare penetrations exist. A two inch drying air line and an electrical conduit would have to be brought through the wall also. A $480 \mathrm{~V}$ power circuit would have to be identified and brought to the outside of the storage area. The drain from the storage area would have to be modified so that it could drain into both VES-NCD-123 and VES-NCD-129. Finally, the leaching system equipment would have to be purchased and installed. It should be noted that the ventilation exhaust duct for the storage area is located in the northeast corner of the room and could limit the amount of space available for installation of the leaching system.

\subsubsection{Advantages and Disadvantages to Modifying the Equipment Storage Area}

There are several drawbacks to modifying the Equipment Storage Area for filter leaching. First, there would be a significant cost becaluse of the amount of existing equipment, piping, etc. which would have to be moved or modified. As noted earlier, a recent cost estimate for modifying the Equipment Storage Area for remote decontamination came in at almost two million dollärs. The cost of installing a filter leaching sy'stem would equal or exceed this value. Second, modifying the Equipment Storage Area would take away the only approved storage location for moderately contaminated $(<50 \mathrm{R} / \mathrm{hr}$ total) items. Loss of the storage alrea would either limit the ability to store such items or lead to storage of these items in areas that are not designed or approved for it. Finally, the radiation limits on the Equipment Storage Areal would limit the filters which could be leached in it. While many of the filters currently stored at the ICPP have activity levels low enough to be handled in the Equipment Storige Arat. there are some that could noly be leached in the Filter Handling Cell. This final point is not a major one, but it is important is a dealize that limitations could exist. 


\subsection{Decon Cubicle \#1}

\subsubsection{General}

Decon Cubicle \#1 is one of two decon cubicles located on the first level of the Decontamination Area within the Equipment Decon Room (See Figure 4 on Page 8). The decon cubicles provide isolated areas for hands-on decontamination of items with a high potential for contamination spread. Current radiological controls limit use of the decon cubicles to items with radiation levels less than $300 \mathrm{mR} / \mathrm{hr}$ (gamma) at contact. The Zone III contamination rating allows items with high contamination potential to be worked on. The decon cubicles were designed for maintenance work on equipment that must be disassembled and decontaminated before maintenance work can begin. The initial rinsing of smaller items, necessary before they can be transferred to other areas for further decontamination work, often takes place in the decon cubicles. Larger items, or cleaning equipment such as soak tanks, can be brought into the cubicles by removing the cubicle hatch and lowering the items into the cell using the Equipment Decon Room $30 / 5$ ton bridge crane.

\subsubsection{Physical Description}

One $10.33 \mathrm{ft} \times 13.75 \mathrm{ft}$ hatch allows access to the interior of the Decon Cubicle \#1 from the Equipment Decon Room, and there is approximately 15 feet of clearance between the hatch and the Equipment Decon Room bridge crane. Decon Cubicle \#1 measures $12.33 \mathrm{ft} \times 15.75 \mathrm{ft}$ inside, and has a 12 foot ceiling. All walls are one foot thick concrete, and there are no shielding windows. A single door provides access from the cubicle entry corridor. The entire floor and bottom six inches of the walls are lined with stainless steel. The remainder of the walls are epoxy-coated concrete. All piped fluids and gases required for a filter leaching system are readily available outside Decon Cubicle \#1, and quick-connect fittings for decontamination solution, raw water, high and low pressure air, and high pressure steam are already available inside. Decon Cubicle \#1 has a gutter drain thatcan drain to either VES-NCD-123 or VES-NCD-129. Facility drawings indicate that the cubicle ventilation system is designed to maintain a negative pressure of -0.5 inches WG within the room. Normally, ventilation air comes in from the Calciner Supply Air System, is pulled into the cubicle exhaust outlet, and ultimately goes to the scrubber system. No decontamination systems or fire protection systems are present inside the cubicle. Lighting inside Decon Cubicle \#1 is sufficient for remote handling operations. No provisions exist for remote handling of any kind.

\subsubsection{Modifications Required to Install Leaching System}

Moderately extensive modifications would have to be made to install a second filter leaching system in Decon Cubicle \#1. The system controls would have to be located on the west wall of the cubicle since it is the only one that is readily accessible. Three small process fluid pipes, two electrical conduits, and two cilpped vent pipes currently cross this wall and would have to be removed or rerouted to install a leaching system. A small work table inside the cubicle would probably have to be removed to install a full-sized leaching system. A shielding window would have to be added, and the interior walls would have to be lined with stainless steel. A pair of master-slave manipulators would also have to be added. Ceiling clearance inside the cubicle is too low for installation of an overhead crane, but a PaR could be installed inside the cubicle on the east wall for heavier lifting operations. This recommendation cannot be made until the size and number of filters to be leached has been decided. All piped fluids and galses required for a leaching system are readily available outside the cubicke, but would hate to be brought through the wall since no spare penetrations exist. A two inch drying air line and an electrical conduit would have to be brought through the wall also. A $480 \mathrm{~V}$ power circuit would have to be identified and brought to the outside of the cubicle. The Decon Cubicle \#1 drain can be manually valved inside the cubicle to empty into either VES-NCD-123 or VES-NCD-129, but remotely operated valve actuators would 
have to be added to operate the valves from outside the cubicle. Finally, the leaching system equipment would have to be purchased and installed.

\subsubsection{Advantages and Disadvantages to Modifying Decon Cubicle \#1}

Decon Cubicle \#1 would have limitations if it were modified into a leaching room, but there would also be some intrinsic advantages. The major limitation would be the allowable radiation limits within the cubicle because its walls are only one foot thick concrete. Preliminary calculations by a WINCO radiation engineer indicate that activity within the cubicle would have to be limited to approximately $1 \mathrm{R} / \mathrm{hr}$ gamma to keep body fields below $5 \mathrm{mR} / \mathrm{hr}$ outside the cubicle. This would prevent leaching of higher activity filters without a special procedure or additional shielding, but many of the Fluorinel Dissolution Process (FDP) and Atmospheric Protection System (APS) filters would fall below this limit. The other significant limitation to installing a leaching system in Decon Cubicle \#1 is the lack of room to install an overhead crane within the cubicle. Unless a PaR were installed to perform heavier lifting operations, leaching in the cubicle would have to be limited to the smaller FDP dissolver off-gas (DOG) filters, which could be handled individually using master-slave manipulators. One advantage to modifying Decon Cubicle \#1 into a leaching room would be that it would not adversely impact Decon capabilities. There are two virtually identical decon cubicles, and they are used so infrequently that losing one would have virtually no effect. Another advantage is the accessibility of the cubicle for modifications. Its location in the Equipment Decon Room leaves the area above and adjacent to the west wall wide open. The few pipes and conduits mounted on the outside of the west wall (with the exception of a one inch sample gas line) could all be removed because they no longer serve any purpose. This would simplify installation of a leaching system immensely. The final advantage to converting Decon Cubicle \#1 into a leaching room would be an enhancement of facility decon capabilities. When not being used for filter leaching, the cubicle could be used as an alternative to the Decon Cell. Smaller items whose activity levels are too high for hands-on decontamination, but not high enough to require treatment in the Decon Cell, could be remotely decontaminated in the cubicle. 


\section{FILTER BACKLOGS AND THROUGHPUTS}

\subsection{Filter Backlogs}

There are approximately 300 spent HEPA filters of various sizes currently stored at the ICPP (see Table 1). Storage space for these filters is limited, and normal facility operations are adding to this backlog. Future generation of spent filters is difficult to quantify because the role of the ICPP is changing. There are approximately 100 APS/VOG filters currently in service, but these filters are changed very sporadically. The Waste Calcining Facility (WCF) and the Fluorinel Dissolution Process are down, so no significant spent filter generation is expected from these sources. The filters at the RWMC are old ICPP filters which are expected to be returned to the ICPP eventually. The only facility which could significantly add to the filter backlog is the NWCF, and spent filter generation will be dependent on frequency and duration of operation of the calciner. NWCF personnel have estimated NWCF spent filter generation at two filters per year when the calciner is down and two filters per month when the calciner is operating.

Table 1. Number of spent HEPA filters currently at the ICPP.

\begin{tabular}{|c|c|c|c|}
\hline Source & Inventory & Radiation Level & Filter Dimensions \\
\hline $\begin{array}{c}\text { Fluorinel } \\
\text { Dissolution } \\
\text { Process (FDP) }\end{array}$ & $\begin{array}{c}93 \text { (DOG) } \\
34 \text { (DOG, out of cell) } \\
2 \text { (COG) }\end{array}$ & $\begin{array}{c}5-200 R \\
5 R \\
500 m R-1 R\end{array}$ & $\begin{array}{c}8^{\prime \prime} \times 8^{\prime \prime} \times 6^{\prime \prime} \\
12^{\prime \prime} \times 12^{\prime \prime} \times 8^{\prime \prime} \\
2^{\prime} \times 2^{\prime} \times 1^{\prime}\end{array}$ \\
\hline $\begin{array}{c}\text { New Waste } \\
\text { Calcining } \\
\text { Facility (NWCF) }\end{array}$ & 127 & $>50 \mathrm{R}$ & $2^{\prime} \times 2^{\prime} \times 1^{\prime}$ \\
\hline $\begin{array}{c}\text { Radioactive Waste } \\
\text { Management } \\
\text { Complex (RWMC) }\end{array}$ & 34 & $>50 \mathrm{R}$ & $2^{\prime} x 2^{\prime} x 1^{\prime}$ \\
\hline $\begin{array}{l}\text { Atmospheric } \\
\text { Protection System } \\
\text { / Vessel Off-Gas } \\
\text { (APS/VOG) }\end{array}$ & 12 & $<10 R$ & $2^{\prime} \times 2^{\prime} \times 1^{\prime}$ \\
\hline $\begin{array}{l}\text { Waste Calcining } \\
\text { Facility (WCF) }\end{array}$ & $10-12$ & $>25 \mathrm{R}$ & $28 " x 24 " x 8^{\prime \prime}$ \\
\hline
\end{tabular}

\subsection{Filter Throughputs}

Accurately estimating the filter throughput of the existing HEPA filter leaching system is difficult. Many factors will significantly affect throughput rate including drying time, manpower availability, sampling requirements, simple analysis turnaround, equipment breakdown frequency, and filter failure rate. Two different approaches are presented that make a reasonable estimate of filter throughput.

\subsubsection{Computerized Throughput Model}

Personnel in WINCO's Applied Technology Department have developed a detailed Turbo Pascal computer model to simulate operation of the leaching system. The computer model 
represents the leaching system as a series of discrete, interdependent steps and visually moves filters through the steps in a continuous process (See Figure 5). The model is extremely flexible, allowing the user to change many of the parameters including time required to perform each step, the number of shifts and days of the week the system is operated, and the filter failure rate. Entire steps can also be added or removed as necessary. The model is still being refined, and its throughput estimates may be somewhat optimistic, but they should be reasonably close to what can actually be achieved. Several significant assumptions are implicit in the model. It assumes continuous operation of the leaching system (no shutdown for Decon Cell work), a 15\% filter failure rate, some allowance for equipment breakdown and repair in the time steps, and no shutdown of the leaching system while leached filters are removed from the Decon Cell. It also assumes that the pre-leach storage area will always be kept full and that the leaching acid will always be available. The time periods associated with each step in Figure 5 are estimates based primarily on conversations with Decon personnel. With the time periods shown, the system bottlenecks at the drying step (step 13). If the drying time is reduced to 9 hours, the system bottlenecks in the sample leg (steps 10,11, and 12); but the corresponding drop in throughput is not significant.

This model estimates throughput for a 100 calendar day campaign at 82 filters using two shifts five days a week and 57 filters using one shift five days a week. This equates to a yearly throughput rate of approximately 300 filters for two shifts and 210 filters for one shift if the system were operated continuously. Even if these values are off by a factor of two, the entire existing backlog could theoretically be worked off in two to three years. Factors such as major equipment breakdowns, higher priority decon projects, and environmental restrictions make it unlikely that the system will be able to operate continuously. Table 2 indicates what predicted throughputs would be if the system were not operated continuously.

Table 2. Predicted filter throughput as a function of system operation.

\begin{tabular}{|c|c|c|c|c|}
\hline \multirow[b]{2}{*}{$\begin{array}{c}\text { Yearly } \\
\text { System } \\
\text { Operation }\end{array}$} & \multicolumn{2}{|c|}{ One Shift Operation } & \multicolumn{2}{|c|}{ Two Shift Operation } \\
\hline & $\begin{array}{c}\text { Yearly } \\
\text { Filter } \\
\text { Throughput }\end{array}$ & $\begin{array}{l}\text { Years to } \\
\text { Process } \\
\text { Backlog }\end{array}$ & $\begin{array}{c}\text { Yearly } \\
\text { Filter } \\
\text { Throughput }\end{array}$ & $\begin{array}{l}\text { Years to } \\
\text { Process } \\
\text { Backlog }\end{array}$ \\
\hline $100 \%$. & 210 & 1.4 & 300 & 1.0 \\
\hline $75 \%$ & 158 & 1.9 & 225 & 1.3 \\
\hline $50 \%$ & 105 & 2.9) & 150 & 2.0 \\
\hline $25 \%$ & 53 & 5.7 & 75 & 4.0 \\
\hline
\end{tabular}

\subsubsection{Batch Throughput Model}

An alternate, and less complicated method to estimate filter throughput is to assume the leaching system will be run in a batch mode. A batch of three large filters (or twelve small filters) could be processed through the system in five working days with two shift operation (see Figure 6). Time estimates for each step in this model are based primarily on the values used in the 

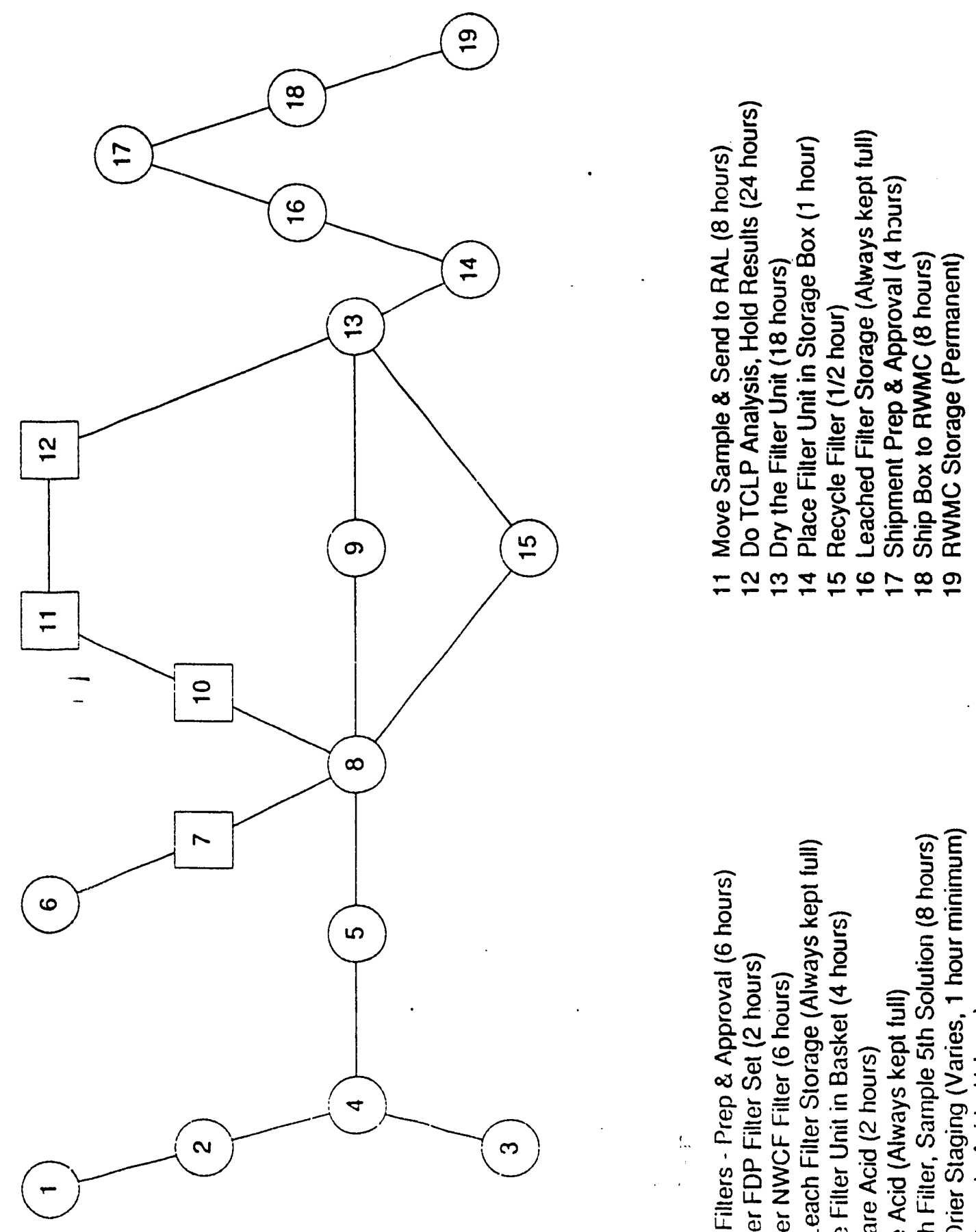

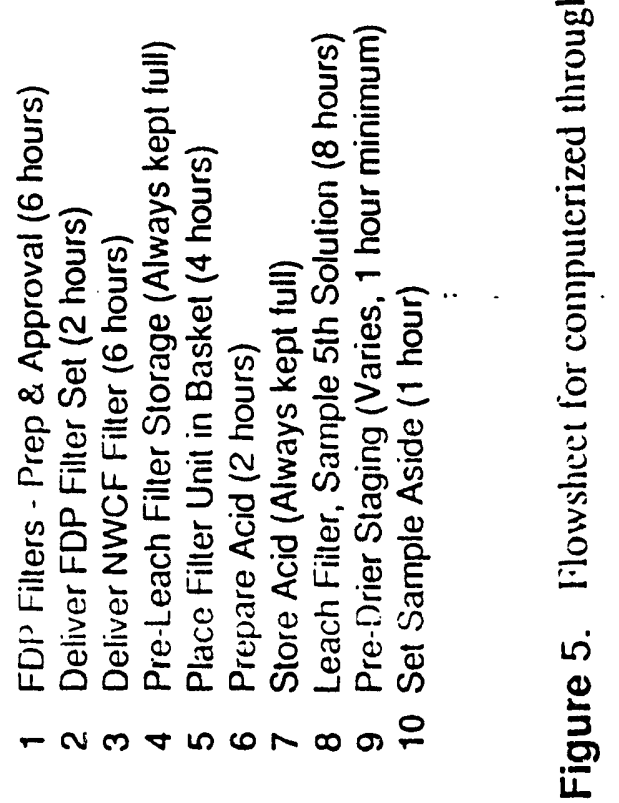




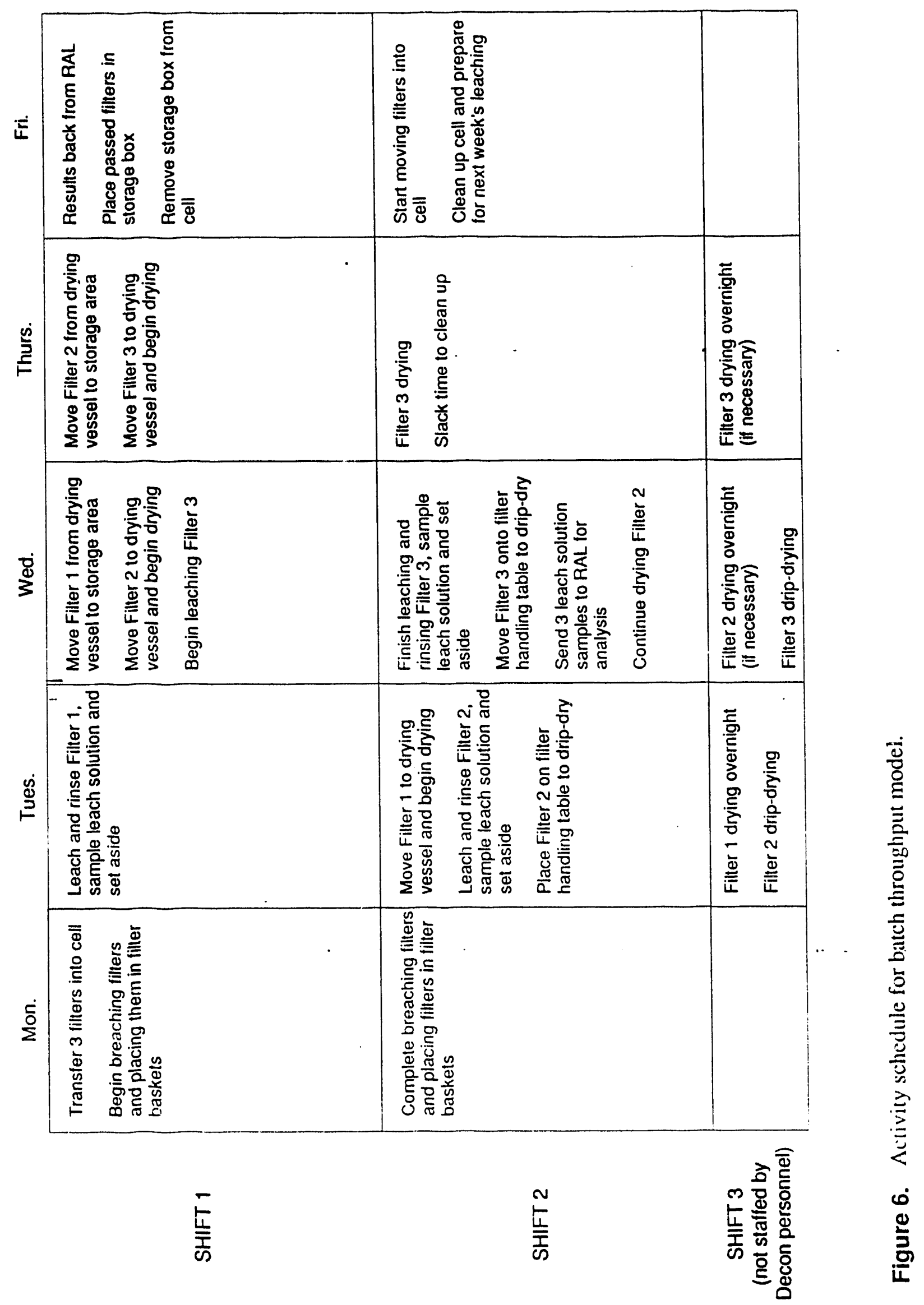


computerized throughput model, but some have been shortened slightly to fit two shift batch operation. It should be noted that there is some slack time on Thursday and Friday second shifts that could be used to compensate for delays earlier in the week.

A processing rate of three filters per week would equate to a yearly throughput rate of approximately 150 filters, which would work off the filter backlog in approximately two years. This yearly throughput value assumes full-time operation of the system, and does not consider time lost to equipment breakdown and repair. Even so, these values should be fairly realistic if filter leaching is given a priority status. If system operation is intermittent, throughputs would be reduced proportionately. 


\section{CONCLUSIONS AND RECOMMENDATIONS}

Based on all present information, installation of a second HEPA filter leaching system is not recommended. If filter leaching is given priority and adequately staffed, throughput estimates indicate that the current filter backlog could be processed in less than four years using only the existing filter leaching system. If filter leaching is not given priority, or is inadequately staffed, a second leaching system would be of little or no benefit. Additionally, the permitting, design, and installation of a second leaching system would be expensive, take several years to complete, and once installed it would require additional staffing for operation. Installation of a second leaching system in any of the three locations discussed in this report would also place limitations on Decon operations. If the Decon Cell were modified for filter leaching, another area would have to be modified for decontamination of highly contaminated items, and the ability to decon items from the Calciner side without direct, hands-on contact would be lost. If the Equipment Storage area were modified for filter leaching, the only approved storage area for highly contaminated items would be lost and there could be restrictions on the radiation levels of spent filters. If Decon Cubicle \#1 were modified for filter leaching, it would probably be limited to treatment of smaller, lower activity filters unless additional radiation shielding were added.

If the decision was made to install a second leaching system, modificaton of Decon Cubicle \#1 to treat only the FDP DOG filters would be the recommended option. The FDP DOG filters are somewhat unique because they are much smaller than the other filters ( 8 in $\times 8$ in $\times 6$ in) and contain a layer of small silica gel beads. It is not known what effect the silica gel will have on leaching. The best information available indicates that there are currently 93 spent FDP DOG filters at the ICPP, and the cessation of fuel reprocessing makes it unlikely that many more will be produced. If Decon Cubicle \#1 were converted to a leaching room dedicated to leaching only individual FDP DOG filters, the expense of conversion would be reduced because no PaR or crane would be required, and the smaller leaching system equipment would be less expensive. The leaching process could also be tailored to leaching these specific filters. When all the FDP DOG filters had been leached, the leaching system could be removed and the cubicle could be dedicated to remote decontamination of small, moderately radioactive items; a capability which is not presently available. 

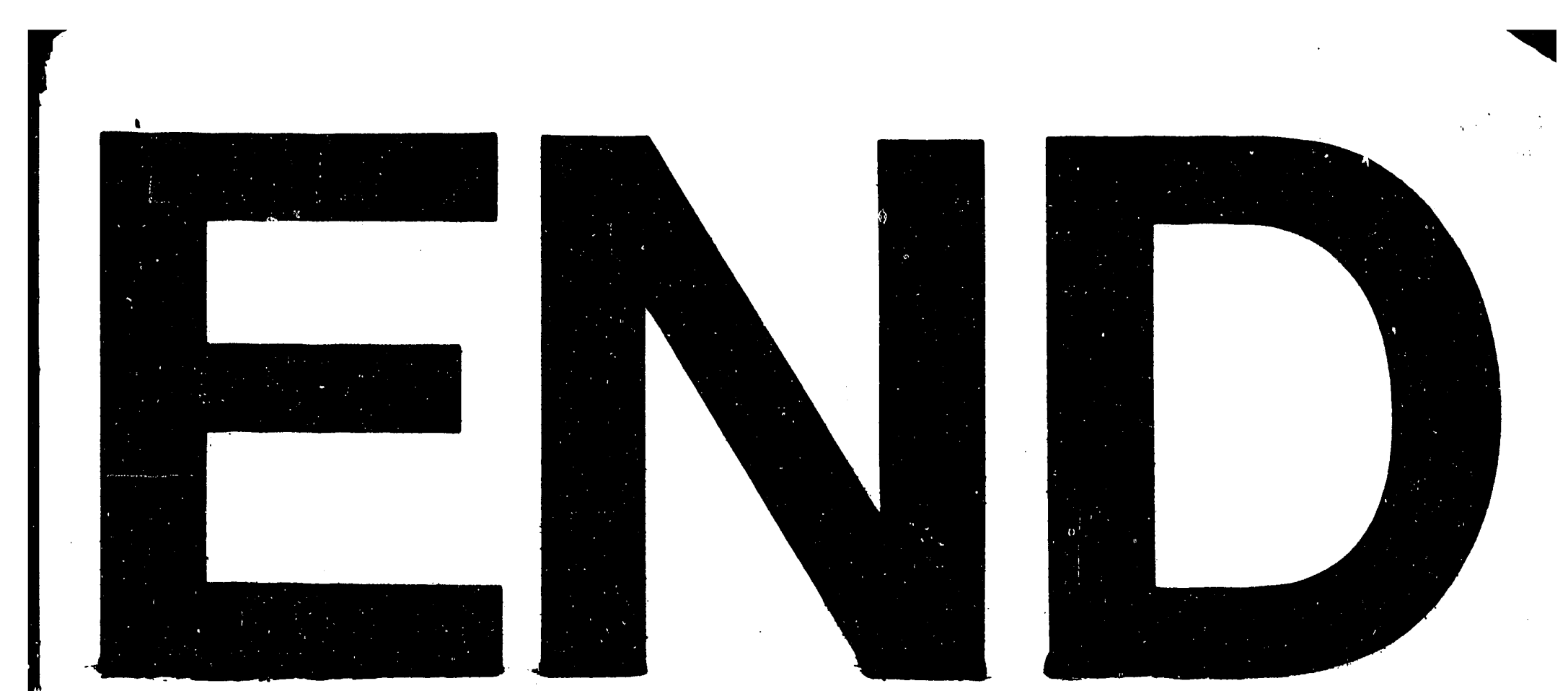

$x$
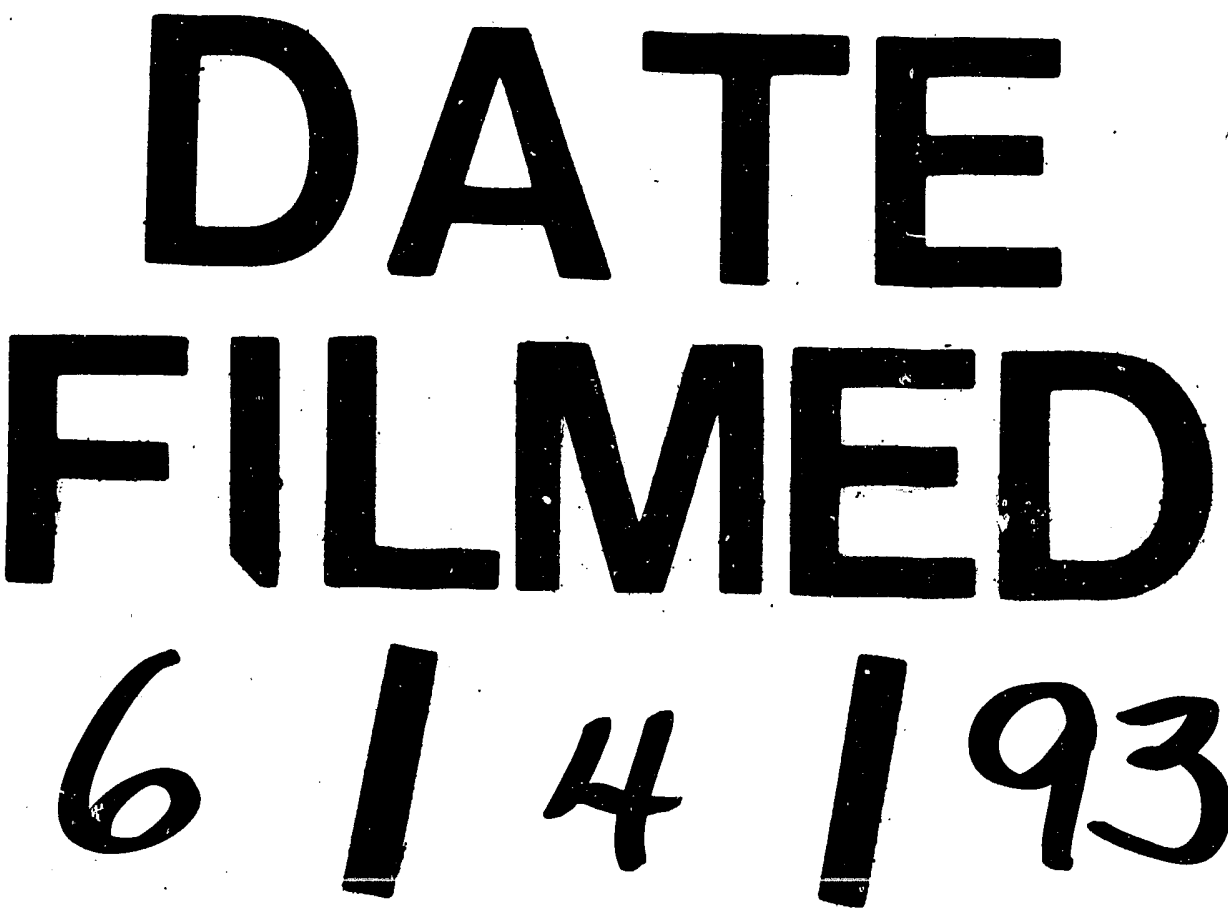

4

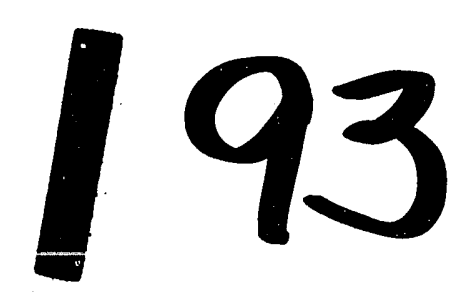

